\title{
The Icelandic Open Access Barometer 2013
}

\author{
lan Watson and Guðmundur Á. Pórisson
}

\begin{abstract}
In September 2013, we surveyed journals published in Iceland and found that 51 of them could be classified as "scholarly," publishing quality-controlled research that aims to contribute to general knowledge. Of these 51 journals, 16 were completely open, with articles available for digital download from the moment of publication; 20 were completely behind toll barriers (published only on paper and sold to libraries and subscribers); and the remaining 15 released their articles openly in digital form after an embargo period of varying length. No journals offered online subscriptions. The relatively large penetration of open access in Iceland was a welcome surprise. Interestingly, more than three-quarters of the journals surveyed published primarily in Icelandic. Many of the embargoed journals made articles available on the website timarit.is, which has limited facility for whole-article downloads; the issue of convenient archival repositories for Icelandic journal content appears to need attention.
\end{abstract}

Ágrip: I september 2013 gerðum við könnun á tímaritum sem gefin eru út á Íslandi. Í ljós kom að 51 peirra mátti flokka sem "fræðileg": í peim birtast greinar um gæðastýrðar rannsóknir sem miða að pví að bæta við og útvíkka almenna pekkingu. Af pessum 51 fræðiritum voru 16 alveg opin og greinarnar aðgengilegar á rafrænu formi á Netinu um leið og pær voru birtar. 20 ritanna voru á bak við áskriftarvegg (greinar aðeins aðgengilegar á prenti gegnum áskrift til bókasafna og einstaklinga). Hin 15 ritin sem eftir eru gerðu greinar sínar aðgengilegar á opinn hátt á rafrænu formi á Netinu eftir mislanga birtingartöf (e. embargo) eftir að prentútgáfan kemur út. Ekkert ritanna bauð upp á rafræna áskrift á Netinu. Pessi tiltölulega mikla útbreiðsla opins aðgangs (OA) á Íslandi kom okkur pægilega á óvart. Áhuga vekur að rúmlega prjú af hverjum fjórum ritum sem við könnuðum birta aðallega á íslensku. Mörg af ritunum sem eru með birtingartöf gera greinar sínar aðgengilegar gegnum vefinn timarit.is sem er pó mjög takmörkuð lausn hvað varðar að hlaða niður greinum í heilu lagi. Einsýnt er að pað er skortur á hentugum lausnum fyrir langtíma varðveislu á efni íslenskra fræðirita.

Citation/Tilvísun: lan Watson and Guðmundur Árni Pórisson, "The Icelandic Open Access Barometer 2013," Samtíd 1 (2013), 6. http://dx.doi.org/10.12742/samtid.2013.6

Received/Móttekið: 2013-10-21. Accepted/Sampykkt: 2013-11-13. Published/Birt: 2013-12-23.

(c) 2013 Authors/Höfundar. This open-access article is published under the terms of the Creative Commons Attribution License, version 3.0 / Greinin er birt í opnum aðgangi undir CC-BY 3.0 leyfi (http://creativecommons.org/licenses/by/3.0) 


\section{Introduction}

We set out to survey Icelandic academic journals and in particular to report on their open access policies. Originally, the project grew out of the need to prepare a mailing list for an editors' workshop at the Icelandic Open Access conference in October 2013.

Our criteria for inclusion were that journals had to be currently active and of a scholarly nature (either wholly or partly). For the purposes of this study, a "scholarly" journal is one that publishes research-based writing with source attributions, the ambition of contributing to general knowledge (rather than, for example, disseminating news), and some kind of quality control. Quality control methods varied; many journals, but not all, employed some form of "traditional" peer review on published articles.

This loose characterization of what counts as scholarly may not satisfy everyone. However, we did not belabor our inclusion decisions, which were not made for their own sake or intended as a value judgement. Rather, our criteria were a practical means to the end of creating a sample.

Journals which had not published in the last three years were not included. "Yearbooks" (árboekur), published by some Icelandic organizations, were included only if the content was journal-like (with multiple authors and scholarly intent). Newsletters were not included, but a few periodicals published by professional associations which combine both academic articles and news were included (an example is the journal Iðjupjálfinn, published by Iceland's association of occupational therapists).

We developed our journal list with the assistance of a database search by staff at Iceland's national library. This produced a list of current periodicals that was useful enough to be used as a base but flawed enough that it had to be extensively pruned (often after examining the relevant periodical or its website) and added to (with the aid of personal knowledge and the periodical shelves in the national library).

One of the administrative offices at the University of Iceland performs an annual survey of domestic scholarly journals each year. This is done in connection with the mandated task of determining how many points academic employees in the state university system should receive for publications. Journals are ranked and point amounts depend on the ranking. While the names and rankings of the journals evaluated are made public (though not in published form), ${ }^{1}$ the data on the journals are not, and only some Icelandic journals (39 in 2012) respond to the university's survey. We

1 See "Flokkun íslenskra vísindatímarita. Tillaga Vísindanefndar opinberra háskóla til Matskerfisnefndar. Sampykkt 6. desember 2012," unpublished document circulated by the Office of Research Affairs (Vísindasvið), University of Iceland, December 2012. 
checked our journal list against the ranked journals and made sure that we had evaluated all the journals surveyed by the university for inclusion in our data set.

In the end, our final list contained 51 academic journals published in Iceland. We cannot rule out that we might have unjustly omitted a journal or two. However, we are confident that our list is a good reflection of the academic journal landscape in Iceland in September 2013. Given that our central aim was to gauge the overall level of openness in this landscape (as opposed to determining the "scholarliness" of individual journals), we believe selection nuances have little impact on the study findings.

Using the journals' websites (typically found via a Google search), paper issues, and entries in the Icelandic library catalogue, we then checked on the access policies of each journal as well as a few other features. We grouped journals into three main categories according to their level of openness:

Open access - available electronically and without cost at the moment of publication. Delayed access - available electronically and without cost after an embargo, or delay, of varying length.

Toll access - available in print only, or available electronically only by paid subscription.

We use the term "open access" in the sense commonly referred to as gratis, which means that journal content is free to read online even if copyright may restrict other reuse of the material. ${ }^{2}$ As the survey was focused on electronic availability, we did not consider print-only journals available to read for free at public libraries as open.

There is now a small literature on the history of open access in Iceland, ${ }^{3}$ and even on open-access journal publishing in Iceland, ${ }^{4}$ but our survey is the first to report systematically on the local open-access journal landscape. Internationally, it is one of a growing number of studies that report on the level of openness of scholarly publications. There are efforts underway in other countries too (such as Denmark) to measure openness within national borders. ${ }^{5}$ In most countries, though, it is probably impractical to count all active scholarly journals, making studies exactly comparable to ours

2 On the distinction between gratis and libre open access, see Peter Suber, "Gratis and libre open access," SPARC Open Access Newsletter, August 2008 (archived at http://www.sparc.arl.org/resource/gratis-and-libre-open-access).

3 Most recently, Solveig Thorsteinsdottir, "The important developments within academic publishing and OA in Iceland: a short overview," ScieCom Info 9, 2 (2013)

(http://journals.lub.lu.se/index.php/sciecominfo/article/view/7294).

4 Ian Watson, “Starting an open access journal in Iceland," ScieCom Info 5, 3 (2009) (http://www.sciecom.org/ojs/index.php/sciecominfo/article/viewFile/1765/1394).

5 The Dansk Open Access Barometer maintains a web site at http://projekter.bibliotekogmedier.dk/projekt/dansk-open-access-barometer. 
hard to execute. Many studies focus on the percentage of articles published in open access, rather than the percentage of journals. ${ }^{6}$

\section{Survey results}

Of the 51 journals surveyed, 16 were completely open, meaning that articles were available to all as digital downloads, for free, as soon as they are published. 20 were published only on paper, and made available to subscribers for a fee. 15 journals were embargoed, meaning that articles were first published on paper and then became available to all for free in digital form after a time period which ranged from 9 months to 11 years. ${ }^{7}$ Of these 15 embargoed journals, the majority (nine) were subject to an embargo period of two years or less. Figure 1 illustrates these statistics; journal names are listed in Table 1.

Very roughly, it is currently possible to say that a third of Icelandic academic journals are completely open and digital, a third are available digitally after an embargo period, and a third are toll-access and available on paper only. One could also say that half of Icelandic journal articles are freely available within two years of publication, while half are not. (Interestingly, no Icelandic journals were available digitally by subscription.)

Language. We also made a note of the principal language of each journal. 39 journals published articles principally in Icelandic, five journals published articles principally in English, and seven journals published regularly in more than one language (usually Icelandic and English).

Number of articles per year. We tried to count the number of scholarly articles each journal published in its most recent full year of publication (usually 2012). In practice, it is impossible to carry out this task scientifically, as it is often hard to say what qualifies as an article. We were able to come up with a count for 42 of the 51 journals. Aggregately, those 42 journals published a total of 476 scholarly articles, or an average of 11.3 articles per journal per year. However, these figures should be considered only as rough indications. The most active journals were Loknablaðið (48 articles), Stjórnmál og Stjórnsýsla (28 articles), Netla (27 articles), and Ritið (24 articles).

6 One of the earliest and best-known of these is Bo-Christer Björk et. al, "Open access to the scientific journal literature: situation 2009," PLoS ONE 5(6): e11273 (http://dx.doi.org/10.1371/journal.pone.0011273).

7 The journals with the very longest embargo periods appeared to have a very irregular schedule for putting digital versions of issues online rather than a systematic delay. 
Figure 1. Digital availability of Icelandic scholarly journals in September $2013(N=51)$.

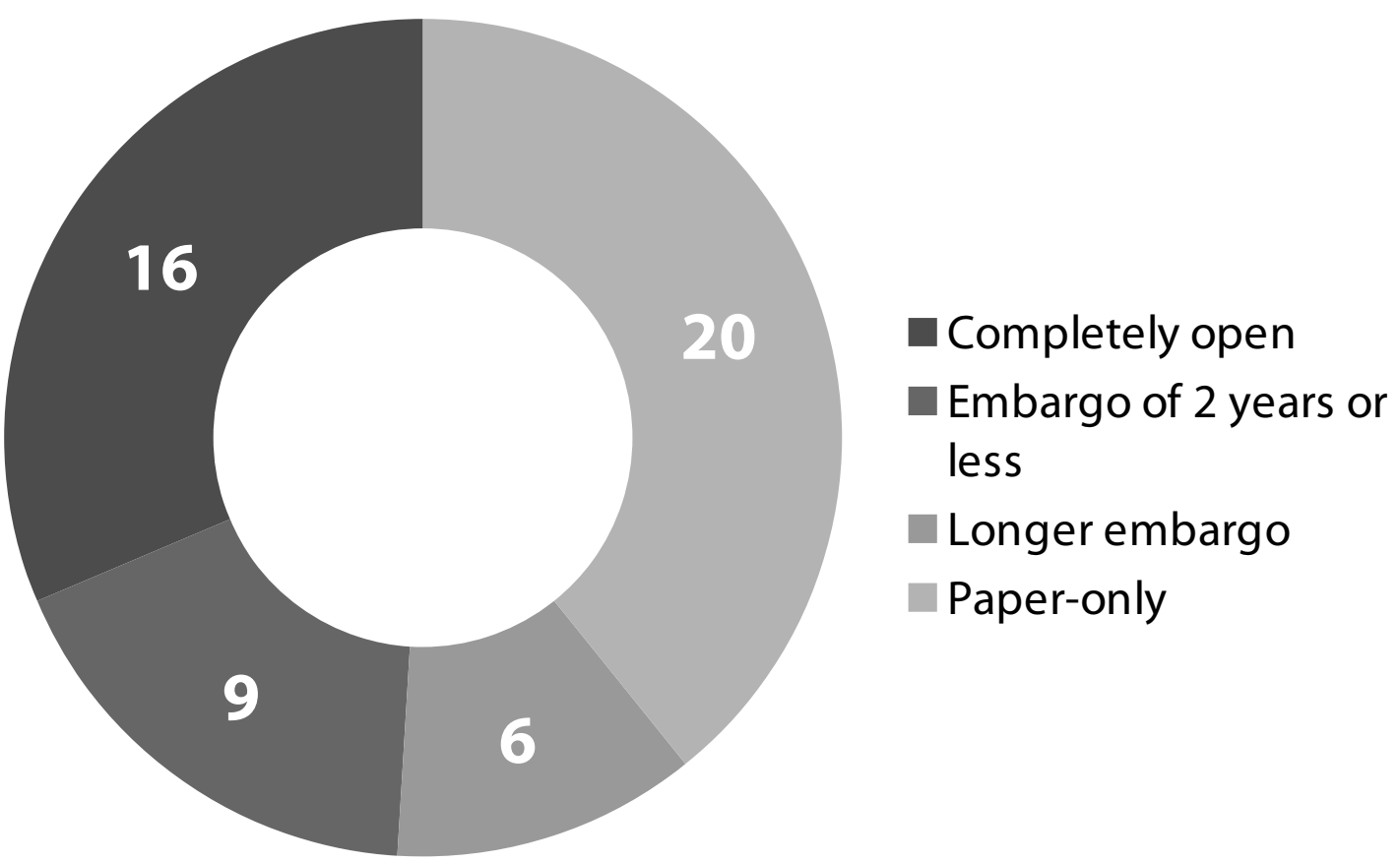

Table 1. Icelandic scholarly journals grouped by level of openness, September 2013.

Árbók VFÍ/TFÍ, Bautasteinn, Icelandic agricultural sciences, Iðjupjálfinn, Íslenska Completely pjóðfélagið, Læknablaðið, Landabréfið, Ljósmæðrablaðið, Málfríður, Netla, open Nordicum-Mediterraneum, Samtíð, Stjórnmál og stjórnsýsla, Tannlæknablaðið, Tímarit hjúkrunarfræðinga, Tímarit um viðskipti og efnahagsmál

Short embargo period (up to 2 years)

Andvari, Bókasafnið, Hugur, Glíman, Gripla, Milli mála, Sálfræðiritið, Tímarit um menntarannsóknir, Uppeldi og menntun

\section{Longer} embargo period Acta Botanica Islandica, Árbók Hins íslenzka fornleifafélags, Îslenskt mál og almenn málfræði, Náttúrufræðingurinn, Saga, Tímarit lögfræðinga

Archaeologia Islandica, Bliki, Glæður, Jökull, Jón á Bægisá, Lögfræðingur, Only published Lyfjatíðindi, Ólafía, Orð og tunga, Orðið, Ritið, Ritröð Guðfræðistofnunar / Studia on paper Theologica Islandica, Ritröð Lagastofnunar Háskóla Îslands, Skírnir, Són, Stína, Strandapósturinn, Súlur, Tímarit Máls og Menningar, Úlfljótur 
Regularity of publication. We also noted whether a journal was publishing regularly or not. Irregular publishing may be a sign that a journal is in difficulty of one sort of another. But it may also simply reflect that the journal's publishers do not place priority on publishing regularly. In a small society like Iceland (population 320,000), where one or two people may carry most of the weight of a journal, illness or special projects can easily delay publication by a year. Of the 51 journals surveyed, 17 (onethird) had recently had an irregular publication schedule. These journals had either skipped a year or were currently delayed in their publication schedule; we also included in this total one journal whose number of issues per year varied widely. Of these seventeen, six were open-access, four delayed-access, and seven toll-access, a distribution not much different from that of journals overall.

Current content display. Two of the open-access journals used the Public Knowledge Project's special-purpose journal-publishing software (Open Journal Systems or OJS), and another was in the process of switching to OJS. The other 13 open-access journals used their own, home-grown methods to display material. These were of widely varying styles, quality, and utility. Approaches ranged from simple and informal web pages (often subsections within society or institutional websites) to stand-alone websites which were either hand-crafted or built with commercial or open-source content management systems.

Digital content archiving. Of the sixteen open-access journals, six (all in health sciences) archived digital content in Hirslan, a repository run by the library of Iceland's national hospital. Content from two journals was archived in Skemman, a repository run jointly by Icelandic universities. The websites timarit.is and rafhladan.is archived material from one journal each. The other six journals archived articles on their website. Most (though not all) of the open-access journals also printed paper copies which were archived in the traditional way on library shelves.

The fifteen delayed-access journals all printed paper copies which were archived on library shelves. At the end of the embargo period, most (nine) placed their digital content on the website timarit.is, varyingly as scanned pages or as original born-digital PDFs. Five journals placed open de-embargoed articles on their own web site, and one journal used the Hirslan repository.

Participation in DOAJ, OASPA, CrossRef, and Creative Commons. We noticed that only a small minority of Icelandic open-access journals had linked themselves with the international open access scene. Out of the 16 open-access journals, only six were registered in the Directory of Open Access Journals (www.doaj.org). Only two were members of the Open Access Scholarly Publishers Association (oaspa.org). Also, only two of the 51 journals participated in the CrossRef citation-linking network (crossref.org) and assigned persistent DOI identifiers to their articles. In practice, this 
means that if any of the other 49 journals move their web site or archive site to a different Internet domain, or reorganize the structure of their site, hyperlinks to journal content from other sites will be broken.

Another common feature of the 16 open-access journals surveyed is that they tended not to specify the terms under which their content is published. Most did not mention copyright at all, neither on their website nor in the full-text articles themselves, which strictly speaking means that full copyright applies and further reuse of the material beyond reading online is not permitted. Two journals explicitly stated that their content was published under a standard Creative Commons license (see full text at creativecommons.org) which permits various kinds of reuse that approximate the looser libre sense of open access. It should be noted that it is currently unclear whether Creative Commons licenses are compatible with Icelandic copyright law.

In conclusion, the majority of Icelandic journals offer open or delayed access on a gratis basis, but very few of them actively market themselves as "open" to current or potential readers.

\section{Discussion and recommendations}

Open access is more prevalent than expected. We have often heard the sentiment among the open access advocacy community in Iceland that open access has made less headway in Iceland than in neighboring countries. ${ }^{8}$ We were therefore surprised by the number of journals in Iceland that are available gratis to readers immediately on publication or after a relatively short embargo period. The benefits of open access are appreciated more widely (and perhaps quietly) in Iceland than we had thought, in the sense that much scholarly material is available online.

The Icelandic language is a valued scholarly medium. The point system used by public universities in Iceland rewards academic staff for publishing in "high-impact" international journals which are overwhelmingly in English. ${ }^{9}$ Moreover, the primary public research funding agency in the country (Rannís) favors projects which have an international scope and audience, with the implication that research findings will be published in international journals. Given these conditions, it is noteworthy that more than three-quarters of Icelandic scholarly journals we surveyed publish primarily or

8 Solveig Thorsteinsdottir, for example, mentions a "lack of interest within the academic community" in open access (op. cit.)

9 This is expressed explicitly in the document "Flokkun íslenskra vísindatímarita" (see footnote 1), which states that only articles in Icelandic journals which have been accepted for listing in the Thomson Reuters (ISI) or ERIH databases are eligible to confer the highest rating (15 points) on their authors. 
exclusively in Icelandic, and more than half of the remaining journals publish partially in Icelandic.

If we assume an average of ten articles per journal per year (a reasonable guess given the article numbers reported above), we can roughly estimate that over four hundred scholarly articles are published in Icelandic each year, despite being disparaged by the official, state-run rewards system. It is therefore hard to escape the conclusion that published scholarship in the Icelandic language has an important role, and is valued by readers and editors even as it is devalued in university staffing and research funding decisions.

Archiving and long-term preservation need attention. Our survey brought issues of digital preservation and archiving into clearer focus. Digital archiving on journals' own websites only is not an ideal solution and does not promote long-term preservation and access.

Ten journals archived on the aforementioned timarit.is website, which can apparently be set to automatically release content at the end of its embargo period. But this service (operated by the National Library) allows only page-by-page views and downloads and does not permit users to download a PDF of an entire article. Journals can flag particular pages as the first page of an article, and enable searches by article title, but downloading and hyperlinking to content is very cumbersome. This is likely an artifact of the website's original role, which was to enable access to scanned newspapers, where the concept of the multi-page article is not as crucial as it is in scholarship.

In general, making sure that adequate repositories are available for Icelandic journal content is an area that needs attention. Journal editors and managers need to know what repositories exist and need to be trained to use them.

More journals should participate in open-access initiatives. The costs of DOAJ listings, OASPA membership, and participation in CrossRef s DOI system are low enough to be accessible to all or almost all Icelandic journals. Especially for the most successful journals (such as the ISI-listed Loeknablaðið, which is included in the PubMed biomedical abstract indexing service), the introduction of DOIs strikes us as overdue. We speculate that awareness and training is a greater barrier than cost. Finally, there is a great need in Iceland to clarify the legal foundation of Creative Commons licensing, to translate Creative Commons licenses into Icelandic, and to promote a wider discussion of the appropriate licensing terms for scholarly writing. This would enable more journals to give readers explicit guidelines about what they may do with the articles they read. 


\section{Supplementary file}

We have attached our data to this article in spreadsheet form. A simplified version of the spreadsheet is also available for browsing on the OA Iceland website at this URL: http://opinnadgangur.is/icelandic-oa-barometer/data.

\section{About the authors}

Ian Watson is assistant professor of social science at Bifröst University and editor of the Icelandic scholarly journal Samtíð. Website: www.ianwatson.org. Guðmundur Á. Pórisson works for the University of Iceland Computing Services unit and the Open Researcher \& Contributor ID Initiative - ORCID. Website: gthorisson.name.

IW and GÁP conceived of the study and gathered survey data jointly. IW analyzed the survey data and wrote the initial draft of the paper. GÁP provided comments on the draft and assisted with revisions. Thanks to Hrafn Malmquist and other staff at the National Library who supplied the initial list of Icelandic periodicals. 